\title{
Evaluasi Human Machine Interface Menggunakan Kriteria Usability Pada Sistem E-learning Perguruan Tinggi
}

\author{
Akhmad Qashlim $^{\mathrm{a}, *}$, Toni Prahasto ${ }^{\mathrm{b}}$, Rachmat Gernowo $^{\mathrm{c}}$ \\ ${ }^{a}$ Universitas Al Asyariah Mandar Sulawesi Barat \\ burusan Teknik Mesin Fakultas Teknik Universitas Dipnegoro \\ ${ }^{\mathrm{c} J u r u s a n}$ Fisika Fakultas Sains dan Matematika Universitas Diponegoro
}

Naskah Diterima : 12 Juni 2014; Diterima Publikasi : 21 Juli 2014

\begin{abstract}
Integration HMI with usability in user interface design process is a standart of the success of a website. The design process is done through the approach to the end user to find a problem solution of human machine interface phenomena. It can also generate the maximum level of satisfaction and success of implementation of the website. The purpose of this research is to evaluate HMI using usabilitycriteria to know the application of HMI concept in e-learning and provide proposals for improvements to the HMI. Questionnaire Data were processed using a descriptive analysis and methods of CFA to know the variables that are weakest and which indicators have an important role in shaping the research variables. Evaluation results indicate the application concept of HMI in the e-learning had been done but not the maximum. Data analysis of the results obtained that the main problem lies in the accessibility criteria in the meantime indicator latent variables from forming error prevention, learnability, memorability, visibility and accessibility of influential factor loading values indicated significantly (unidimensionalitas) in shaping the criteria of latent variables in first-order CFA. The end result of this research is the proposal of improvement as a HMI solution in the form of principles and technicsuser interface design. This solution is focused on the development of standards for the quality of the interface in e-learning systems and not on the digital learning content presented on the e-learning system.
\end{abstract}

Keywords: Descriptive analisis; Human machine interface; Usability; Confirmatory factor analisys; Elearning

\begin{abstract}
Abstrak
Integrasi HMI dengan usability dalam proses desain antarmuka pengguna merupakan standar keberhasilan pada sebuah website. Proses desain dilakukan melalui pendekatan terhadap pengguna akhir untuk menemukan solusi persoalan fenomena interaksi manusia dan komputer. Hal ini juga dapat menghasilkan tingkat kepuasan yang maksimal dan kesuksesan implementasi website. Tujuan penelitian ini adalah mengevaluasi HMI menggunakan kriteria usability untuk mengetahui penerapan konsep HMI pada e-learning dan memberikan usulan perbaikan HMI. Data kuesioner diolah menggunakan analisis deskriptif dan metode CFA untuk mengetahui variabel yang paling lemah dan indikator mana yang mempunyai peran penting dalam membentuk variabel penelitian. Hasil evaluasi menunjukkan penerapan aspek HMI pada e-learning telah dilakukan namum belum maksimal. Dari hasil analisa data diperoleh bahwa masalah utama terdapat pada kriteria accessibility sementara itu indikator pembentuk dari variabel laten error prevention, memorability, learnability, visibility dan accessibility menunjukkan nilai loading faktor berpengaruh secara signifikan dalam membentuk variabel-variabel laten kriteria pada first-order CFA. Hasil akhir penelitian ini adalah usulan perbaikan sebagai solusi HMI berupa prinsip dan teknis desain antarmuka. Solusi ini difokuskan pada pengembangan standar untuk kualitas antarmuka dalam sistem e-learning dan bukan pada konten pembelajaran digital yang disajikan pada sistem e-learning.
\end{abstract}

$\underline{\text { Kata kunci: Analisis deskriptif; Human machine interface; Usability;E-learning; Confirmatory factor analisys }}$

\section{Pendahuluan}

Implementasi konsep human machine interface (HMI) dapat membantu memahami proses interaksi dan mengidentifikasi hal-hal yang dapat menyebabkan kegagalan dalam penerapan sistem serta menciptakan sebuah sistem interaktif berkualitas tinggi bersifat akrab dan ramah dengan penggunanya (user friendly) (Bevan, 2009). Standar ini memungkinkan developer sistem untuk mengelola

*) Penulis korespondensi: dongk_86@yahoo.com proses desain dengan memahami dan menciptakan teknologi yang selaras dengan peningkatan kemampuan manusia demi menjamin kualitas perangkat lunak (Zhang dan Galletta, 2006). Proses interaksi manusia dengan komputer dapat mengalami kegagalan dan mempengaruhi perilaku pengguna untuk menerima atau menolak sistem informasi apabila antarmuka dari sebuah sistem kurang familiar dan tidak mampu berkomunikasi dengan baik 
terhadap pengguna (Davids, 1989). Oleh karena itu dalam membangun sistem inforrmasi sebaiknya didasari pada sebuah konsep perancangan yang memperhatikan aspek antarmuka manusia dan komputer (human machine interface) dan melalui pendekatan terhadap pengguna akhir (Hsu et al., 2009).

Antarmuka sistem dapat memberikan efek bagi pengguna melalui banyak cara. Jika hal-hal tersebut memusingkan dan tidak efisien, maka pengguna akan mengalami kesulitan dalam belajar dan menyelesaikan pekerjan mereka dan relatif melakukan lebih banyak kesalahan serta dapat menyebabkan frustasi dan peningkatan stres, penurunan kinerja dan produktifitas, kehilangan motivasi dan semangat pada pengguna serta lebih jauh dapat berakibat kegagalan sebuah sistem (Campbell, 1996; Chalmers, 2003; George dan Otrakji, 2007). Hal inilah yang kemudian disebut sebagai fenomena HMI.

Fenomena HMI lebih cenderung pada kajian tentang kesalahan dalam desain grafik user interface. Fenomena inilah yang menjadikan evaluasi antarmuka mesin dan manusia semakin penting. Evaluasi antarmuka perlu dilakukan untuk mengetahui kualitas, aksesibilitas dan usability dari antarmuka (Nielsen, 1993; Oztekin, 2013).

Studi kasus dalam penelitian ini dilakukan pada sistem e-learning STIMIK AKBA Makassar yang dapat diakses pada http: |le-learning.akba.ac.id. Elearning pada perguruan tinggi lahir sebagai paradigma baru pendidikan modern dan mengarah ke perubahan drastis dalam praktek pendidikan. E-learning kemudian menjadi skala prioritas bagi perguruan tinggi yang berfungsi sebagai metode baru yang menawarkan efektifitas dan efisiensi dalam pembelajaran. Sebagai rumusan masalah dalam penelitian, bahwa evaluasi HMI dengan menggunakan kriteria usability dapat mengetahui sejauhmana sebuah sistem e-learning perguruan tinggi telah menerapkan konsep HMI Evaluasi pada penelitian ini lebih difokuskan pada desain antarmuka sistem yang berkaitan dengan tampilan e-learning serta funsional e-learning yang menyangkut sistem menu navigasi yang tersedia pada sistem e-learning.

\section{Kerangka Teori}

\subsection{Elearning}

E-learning tidak hanya memperkenalkan teknologi baru untuk belajar namun juga diperkenalkan cara baru untuk berpikir tentang belajar. Belajar melalui akses informasi merupakan perspektif yang luas untuk meningkatkan kinerja. Banyak perusahaan, perguruan tinggi bahkan individu yang menggunakan e-learning sebagai sarana pelatihan dan pendidikan untuk peningkatan kualitas sumber daya manusia, peningkatan strategis bisnis dan mutu pendidikan. Elearning bersifat jaringan yang membuatnya mampu memperbaiki secara cepat, menyimpan atau memunculkan kembali, mendistribusikan, dan sharing pembelajaran dan informasi. Persyaratan ini sangatlah penting dalam membangun sistem elearning. (Rosenberg dan Jeffrey 2001).

E-learning pada perguruan tinggi lahir sebagai paradigma baru pendidikan modern dan mengarah ke perubahan drastis dalam praktek pendidikan. E-learning kemudian menjadi skala prioritas bagi perguruan tinggi setelah meluasnya penggunaan internet. Implementasi e-learning diharapkan dapat meningkatkan pengajaran, pembelajaran, informasi pengetahuan peserta didik, keterampilan,atau kinerja lainnya. Tersedianya sumber daya online merupakan syarat utama untuk mendukung hal tersebut (Bhuasiri et al., 2012). Interaksi manusia dan komputer memainkan peran dalam proses pembelajaran dengan memperhitungkan dua aspek utama. Aspek pertama adalah bahwa pengguna pemula perlu belajar bagaimana menggunakan sistem komputer untuk menyelesaikan tugas-tugas tertentu, aspek kedua mengacu pada pendidikan perangkat lunak yang bertujuan untuk mendukung pengetahuan dan keterampilan (Hollender et al., 2010).

\subsection{Usability}

Evaluasi usability merupakan kegiatan yang penting dalam pengembangan sistem interaktif. Rancangan antarmuka pengguna harus melalui iterasi desain dan evaluasi sampai menunjukkan hasil yang memuaskan (Zhang et al., 2007), dan mudah untuk dipelajari (Nielsen, 1993). Evaluasi yang paling relevan untuk sebuah sistem yakni dengan mengindetifikasi faktor usability (Oztekin et al., 2013). Evaluasi usability sebagian besar ditunjukkan oleh interaksi manusia dan komputer (Moha et al., 2007).

Secara operasional., metode evaluasi usabiility dapat dilihat pada Tabel 1.

Tabel 1. Metode evaluasi Usability (Zhang et al., 2007)

\begin{tabular}{|c|c|l|}
\hline Metode & $\begin{array}{c}\text { Pengguna } \\
\text { telibat }\end{array}$ & Peran evaluator kegunaan \\
\hline $\begin{array}{c}\text { Model/ } \\
\text { Metrics- } \\
\text { based }\end{array}$ & Tidak & $\begin{array}{l}\text { menggunakanmodelataualat } \\
\text { untuk menyelesaikanlangkah- } \\
\text { langkah usability }\end{array}$ \\
\hline Testing & Ya & $\begin{array}{l}\text { mengamatipenggunadalam } \\
\text { menggunakansistem;mengm } \\
\text { pulkan danmenganalisisdata } \\
\text { untukmengidentifikasi } \\
\text { masalah. }\end{array}$ \\
\hline Inspection & Tidak & $\begin{array}{l}\text { Reviewantamukapengguna } \\
\text { danmencobanya } \\
\text { untukmenemukanmasalah }\end{array}$ \\
\hline Inquiry & Ya & $\begin{array}{l}\text { Berkomunikasi dengan } \\
\text { pengguna untuk mengetahui } \\
\text { masalah usability }\end{array}$ \\
\hline
\end{tabular}


Secara spesifik tujuanusability sebagai berikut (Preece et al., 2002):

1. Efektif untuk digunakan(efektivitas)

2. Efisien untuk digunakan(efisiensi)

3. Aman digunakan(safety)

4. Memilikiutilitas yang baik(utility)

5. Mudah dipelajari(learnability)

6. Cara penggunaanmudah diingat(memorability)

7. Mudah diakses (Accessibility).

8. Pencegahan kesalahan (Error Prevention)

9. Jarak pandang (Visibility)

\subsection{Confirmatory Factor Analysis(CFA)}

CFA adalah teknik untuk menguji hubungan sebuah variabel baik variabel manifest (observed) dengan konstruk laten (unobserved) atau antara konstruk dengan konstruk. Hubungan tersebut digambarkan dalam sebuah model yang disebut sebagai model pengukuran (Hair, et al., 2010).

\section{First roder construct}

First Order CFA adalah suatu keadaan yang mana satu variabel laten memiliki beberapa indikator yang dapat diukur secara langsung (Gambar 1). Sehingga jenjang pengukurannya hanya dari konstruk ke indikatornya (Latan, 2010).

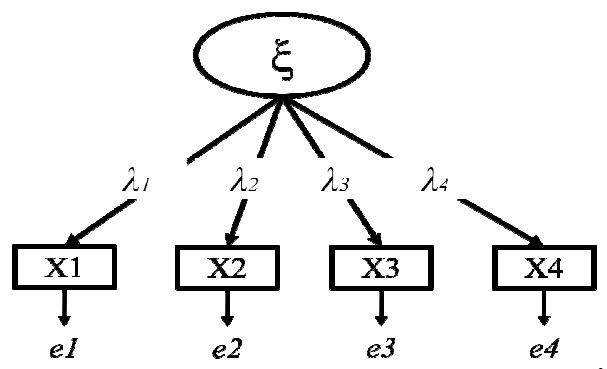

Gambar 1. Ilustrai Model First Order Construct

Keterangan:

$\mathrm{X}=$ Indikator Penelitian

$\xi \quad=$ Variabel laten

$\lambda x 1=$ Loading factor indikator $\mathrm{X} 1$ ke konstruk

$(\xi)$

e1 $=$ Kesalahan pengukuran indikator X1

Error! Reference source not found. diatas merupakan digram jalur yang dapat dituliskan kedalam persamaan pengukuran seperti dibawah ini:

$$
\begin{aligned}
& \mathrm{X} 1=\lambda \times 1 \quad \xi+e 1 \\
& \mathrm{X} 2=\lambda \times 2 \xi+e 2 \\
& \mathrm{X} 3=\lambda \times 3 \quad \xi+e 3 \\
& \mathrm{X} 4=\lambda \times 4 \quad \xi+e 4
\end{aligned}
$$

Persamaan diatas menunjukkan indikator X1, X2, X3, X4 secara bersamaa sama memiliki nilai berupa konstruk variabel laten yang masing-masing koefisien hubungan pengukuran dihasilkan dari nilai loading factor sebesar $\lambda x 1, \lambda \times 2, \lambda \times 3$, dan $\lambda x 4$. Nilai loading factor merupakan nilai estimasi yang mengkur hubungan antara konstruk laten dan indikator-indikatornya sementara el merupakan kesalahan pengukuran dari indikator X1.

\section{Second order construct}

Suatu permasalahan dimana variabel laten memiliki beberapa indikator-indikator yang tidak dapat diukur secara langsung, sehingga memerlukan beberapa indikator lagi (Gambar 2).

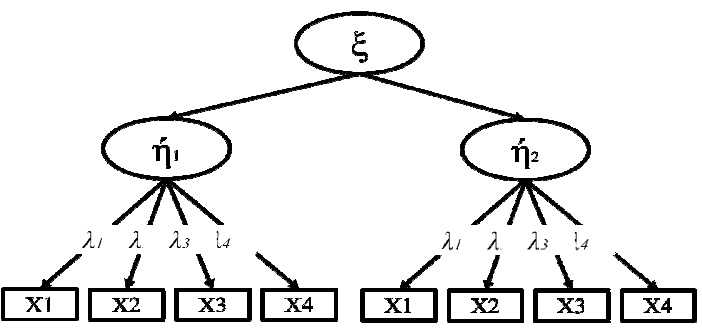

Gambar 2. Ilustrasi Model second order construct

Error! Reference source not found. diatas merupakan model yang akan melalui dua jenjang pengukuran, pertama analisis dilakukan dari konstruk laten ( $\eta 1$ ) ke indikator-indikatornya (X) dan analisis kedua dilakukan dari konstruk laten ke konstruk dimensinya $(\xi)$.

\subsubsection{Evaluasi Model}

Evaluasi Model pengukuran dapat dilakukan dengan melihat nilai berdasarkan ukuran fit (Ghozali dan Fuad, 2008) yaitu:

a. Chi-Square dan Probabilitas

Nilai Probability Chi-squares $>0.05$ menandakan data empiris identik dengan mode pengukuran.

b. Goodness Of Fit Indices (GFI)

Nilai GFI yang lebih besar dari pada 0,9 menunjukkan fit suatu model yang baik

c. Adjusted Goodness Of Fit Index (AGFI) Nilai AGFI yang lebih besar atau sama dengan 0,9 merupakan ukuran standar untuk model fit

d. Comparative Fit Index (CFI)

Nilai yang direkomendasikan untuk penerimaan CFI $>0,90$.

e. Root Mean Square Error Of Appximation (RMSEA). Nilai RMSEA antara 0,05 dan 0,08 mengindikasikan indeks yang baik untuk menerima kesesuaian sebuah model

\subsubsection{Validitas dan Reliabilitas}

Indikator dari validitas suatu model ditunjukkan sebagai dengan nilai t-value pada standardized loading signifikant Jika $\alpha=0,05$ maka 1,96 . Sementara reliabilitas konstruk atau construct reliability (CR) merupakan ukuran reliabilitas (Kehandalan) dan konsistensi secara internal dari variabel-variabel terukur yang menggambarkan suatu konstrak laten Adapun rumus yang digunakan: 


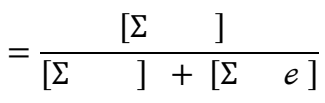

Keterangan:

$i=$ loading factor setiap konstruk

$e=$ nilai error

$n=$ Jumlah items

Jumlah kuadrat dari loading factor untuk masingmasing konstruk dan jumlah error sebuah konstruk merupakan syarat perhitungan dari $\mathrm{CR}$ yang juga merupakan indikator validitas konvergen. Hal ini sering digunakan untuk model SEM. NilaiCR seharusnya diatas 0,7 (Hair et al., 2010).

\subsection{Metode Kualitatif}

Penelitian kualitatif adalah penelitian yang bersifat deskriptif yang mampu menerangkan gejala atau fenomena secara lengkap dan menyeluruh ini merupakan metodologi penelitian lapangan untuk mempelajari fenomena sosial dan masalah yang berkaitan dengan faktor manusia (human factor), tujuannya memberikan pendapat terhadap perasaandan persepsi dari para responden sebagai subjek yang diteliti (Lodico et al., 2006). Penelitian tentang pengguna dengan hal-hal yang mengganggu sering menggabungkan dari penelitian kuantitatif dan kualitatif, atau yang utama kualitatif (Lazard et al., 2010).

Penelitian yang bersifat deskriptif digunakan untuk menyajikan data dengan cara mendeskripsikan atau memberi gambaran terhadap objek yang diteliti melalui data sampel tanpa melakukan analisis dan membuat kesimpulan yang berlaku umum. Analisis deskriptif dapat dilakukan dengan menggunakan teknik analisis indeks untuk menggambarkan persepsi responden atas pertanyaan-pertanyaan yang diajukan (Ferdinand, 2006). Adapun rumus yang digunakan dalam perhitungan indeks jawaban responden adalah sebagai berikut:

$$
\begin{aligned}
= & \left((\% 1 \times 1)+\left(\begin{array}{ll}
\% & 2 \times 2
\end{array}\right)+\right. \\
& (\% 3 \times 3)+\left(\begin{array}{ll}
\% & 4 \times 4
\end{array}\right)+ \\
& (\% 5 \times 5)) \\
/ 5 &
\end{aligned}
$$

\footnotetext{
Keterangan:

$\mathrm{F} 1=$ Frekuensi responden yang menjawab 1

F2 = Frekuensi responden yang menjawab 2

F3 = Frekuensi responden yang menjawab 3

F4 = Frekuensi responden yang menjawab 4

F5 $=$ Frekuensi responden yang menjawab 5
}

\subsection{Human Machine Interface}

Human machine interface (HMI) sebagai displin ilmu yang berhubungan dengan desain, evaluasi dan implementasi sistem komputer interakti fpada umumnya digunakan untuk mempelajari fenomena interaksi yang terjadi disekitar manusia (Hewett et al., 2009). Fenomena interaksi lebih cenderung pada kajian tentang desain interface yang kurang baik serta dampak yang ditimbulkan kepada pengguna. Oleh karena itu arah penelitian utama dari HMI terdiri dariteori dan perilaku manusia ketika berinteraksi dengan teknologi informasi (Hollender et al., 2010).

Persoalan HMI, seperti ketidak mampuan dan kesulitan pengguna untuk mengingat informasi yang disajikan pada layar komputer dan menggunakan website, serta ketidakcocokan fungsional sistem dengan kebutuhan pengguna merupakan masalah disorientasi yang terjadi dalam interaksi manusia dan komputer dan ini merupakan fenomena yang menjadikan interface komputer layak untuk diteliti. (Chalmers, 2003). Hal ini dapat diidentifikasi dan diatasi dengan melakukan penelitian empiris berupa evaluasi yang menggunakan kuesioner dan wawancara. Evaluasi ini membutuhkan keterlibatan pengguna dan kelompok stakeholder yang relevan untuk menganalisis kelemahan dan kekuatan dari interface sistem. Hasil penelitian dapat dilaporkan berdasarkan nilai rata-rata yang dikonversi kedalam bentuk persentase untuk membantu perbandingan. Evaluasi ini mempunyai empat kegiatan desain yang berpusat pada manusia yakni: memahami dan menentukan konteks penggunaan; Menentukan kebutuhan pengguna; Menghasilkan solusi desain dan Evaluasi. Ini merupakan kegiatan yang terjadi selama desain sistem interaktif berlangsung. Hasil akhir dapat melahirkan Konsep solusi HMI sebagai inisiatif usulan perbaikan untuk pengembangan prototipe dan untuk mendefinisikan bentuk produk (Bevan, 2009; Sener dan Wormald, 2007).

Desain antarmuka sistem memiliki disiplin ilmu yang dikenal dengan User Centered Design (UCD) yaitu filosofi perancangan yang menempatkan pengguna sebagai pusat dari proses pengembangan sistem. Desain antarmuka sistem merupakan sebuah pekerjaan yang rumit dan menantang. Salah satu keluhan pengguna akhir saat berinteraksi dengan komputer yaitu ketika antarmuka sistem tidak lagi dapat memenuhi kebutuhan dalam menggunakan sistem hal ini membuat evaluasi antarmuka yang melibatkan partisipasi manusia menjadi sangat penting (Sener dan Wormald, 2007). Dalam desain sistem, kode pemrograman untuk mengimplementasikan antarmuka pengguna biasanya memakan 40-90\% dari seluruh kode program yang diguanakan (Chalmers, 2003). Partisipasi manusia dapat membantu para desainer atau pengembang untuk mengetahui keinginan atau harapan pengguna. Keterlibatan pengguna dalam desain dapat membantu mengidentifikasi masalah fungsional sistem, mengusulkan perubahan atau mengarahkan desain (Sawasdichai, 2007), memperluas pemahaman desainer dan pengembang sistem tentang perilaku 
manusia dalam konteks interaksi manusia dan komputer (O'Connell dan Murphy, 2007).

Keterkaitan antara HMI dengan disiplin ilmu lain disajikan pada Gambar 3. Konteks pengguna berada dalam lingkungan sosial., organisasi dan pekerjaan (U1). Dalam konteks ini ada aplikasi yang menggunakan sistem komputer (U2). Proses penggunaan sistem komputer cocok untuk digunakan sebagai pembelajaran manusia, sistem tailorability, atau strategi lainuntuk bekerja pada aspek manusia dan teknis (U3). Selain penggunaan dan konteks sosial dari komputer, di sisi manusia, juga memperhitungkan pengolahan informasi manusia (H1), komunikasi (H2), dan fisik atau karakteristik pengguna (H3). Di sisi komputer, berbagai perangkat Input dan output telah dikembangkan untuk mendukung interaksi manusia dengan mesin (C1). Perangkat tersebut digunakan sebagai media untuk melakukan dialog (C2). Pada gilirannya teknik ini digunakan untuk menerapkan elemen desain yang lebih besar, seperti antarmuka (C3). Sebagai pendukung dialog dapat membuat ekstensif menggunakan teknik komputer grafis (C4).

Dialog yang kompleks mengarah pada arsitektur sistem yang diperlukan untuk mendukung fitur seperti program interconnec tabel aplikasi, windows, respon real-time, komunikasi jaringan, multi-user interface dan koperasi, dan multi-tasking (C5). Akhirnya, terdapat proses perancanganmelalui pendekatan desain untuk interaksi manusia dan komputer(D1), teknik dan alat untuk menerapkannya (D2), teknik untuk mengevaluasi (D3), dan sejumlah desain klasik untuk studi (D4). Masing-masing komponen dari proses pembangunan terikat dengan dengan pengguna dalam suatu hubungan timbal bali yang saling berpengaruh satu sama lainnya.

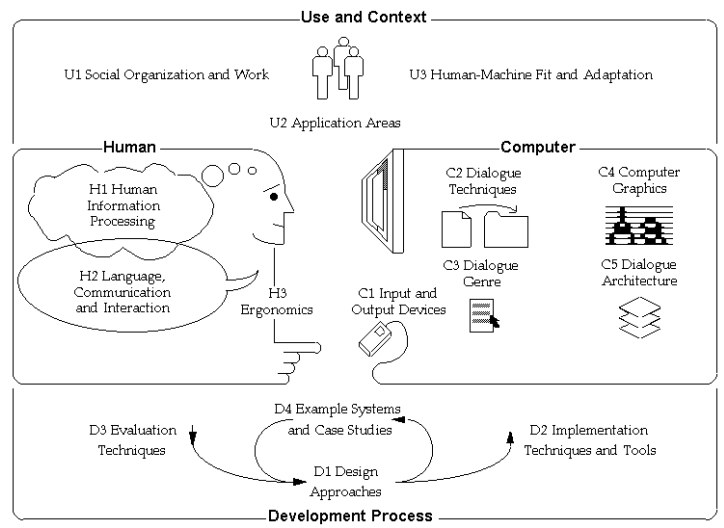

Gambar 3. Ruang Linkup HMI (Hewett et al., 2009)

\section{Metodologi}

\subsection{Prosedur Penelitian}

Prosedur penelitian dimulai dengan investigasi masalah, menentukan kriteria usability, penentuan responden dalam mengevaluasi e-learning.Tahapan selanjutnya dilakukan evaluasi dengan menyebar kuesioner (Lazard et al., 2010), kemudian data diolahdan dianalisis menggunakan analisis deskriptif (Sugiyono, 2003). Selanjutnya dilakukan pengujian confirmatory factor analysis (Hair et al., 2010). Hasil pengolahan data dibuat kedalam diagram pareto untuk dijadikan sebagai prioritas dalam mengetahui masalah utama pada sistem e-learning (Oztekin et al., 2010). Prosedur peneltian yang akan dilakukan ditunjukkan pada Gambar 4.

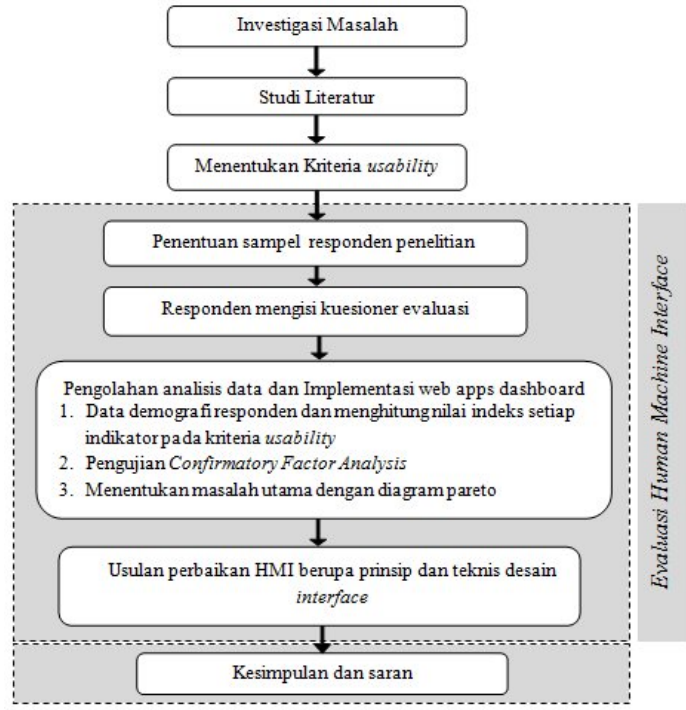

Gambar 4. Prosedur Penelitian

\subsection{Sampel Penelitian}

Pengambilan sampel menggunakan teknik simple random sampling (Sugiyono, 2003). Penentuan jumlah sampel mengacu pada Hair et al. (2010), yang mana jumlah sampel minimum berdasarkan pada kompleksitas model dan karateristik pengukuran dasar model (Tabel 2).

Tabel 2. Ketentuan jumlah sampel (Hair et al., 2010)

$\begin{array}{cc}\text { Jumlah } & \text { Jumlah Konstruk } \\ \text { Sample } & 5 \text { Variable } \\ \text { Minimal 100 } & 7 \text { Variabel } \\ \text { Minimal 150 } & \text { Variabel }+3 \text { konstruk underidentified } \\ \text { Minimal 300 } & \text { Variabel konstruk yang banyak } \\ \text { Minimal 500 } & \text { Vab }\end{array}$

Berdasarkan Tabel 2 maka dapat ditentukan ukuran sampel dalam penelitian ini minimum 100 karena terdapat lima konstruk dalam penelitian ini. Adapun sampel dalam penelitian ini berjumlah 143 responden.

\subsection{Kuesioner dan Pengukuran}

Desain kuesioner merujuk pada oztekin et al., (2010), terdiri dari tiga bagian, pertama karateristik responden meliputi usia, kualifikasi pendidikan, 
pengalaman menggunakan internet dan keterlibatan dalam kelompok belajar. Kedua, pertanyaan tertutup berbentuk multiple coice sebanyak 20 item. Jawaban yang disediakan berdasarkan 5 point skala likert, mulai dari 1. Sangat Tidak Setuju, 2. Tidak Setuju, 3. Netral., 4. Setuju, 5. Sangat Setuju. Ketiga, pertanyaan terbuka yang meminta responden untuk menuliskan bagaimana mereka merespon setiap kesulitan dan kesalahan yang terjadi serta kemudahan apa saja yang didapat dari e-learning.Pertanyaan difokuskan pada 2 hal., pertama, desain yaitu berkaitan dengan tampilan e-learning dan sistem menu yang digunakan, kedua, fungsional e-learning yaitu menyangkut beragam fasilitas dan kemudahan yang tersedia pada sistem e-learning

\subsection{Kerangka Sistem Web Aplikasi Dashboard}

Kerangka sistem dimaksudkan untuk memberikan gambaran tentang alur penelitian yang akan dihasilkan. Sistem pada dasarnya memiliki tiga komponen utama yakni input, proses dan output. Kerangka sistem dalam penelitian ini ditunjukkan pada Gambar 5.

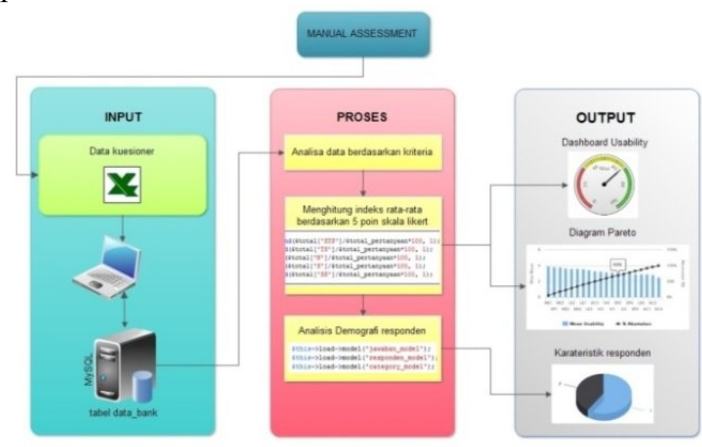

Gambar 5. Kerangka sistem web aplikasi dashboard

\subsection{Pengujian CFA}

Model penilaian menggunakan lima variabel yang membentuk Index Usability yaitu Error Prevention (EP), Memorability (ME), Learnability (LE), Visibility (VI), Accessibility (AC). Ini disebut sebagai variabel laten (unobserved) ditunjukkan oleh gambar elips kemudian dikenali melalui empat indikator empiris sebagai variabel manifest (observed) pada masing-masing variabel laten, ini ditunjukkan oleh gambar balok. Model ini berbentuk unindimensionalitas maka untuk menguji validitas dan reliabilitas konstruk dilakukan dengan first order $C F A$. Hubungan antara variabel laten dengan index usability adalah hubungan yang tidak terukur karena variabel laten yang digunakan merupakan bagian dari usability. Evaluasi model pada dilakukan dengan menggunakan kriteria Goodness Of Fit (GOF). Pengujian validitas konstruk ditunjukkan oleh $t$ value $>1,96$ pada unstandardized loading. sementara construct reliability (CR)lebih besar dari 0,07 akan menunjukkan reliabilitas yang baik. Pengujian ini dilakukan dengan menggunakan alat bantu program
AMOS 21. Hasil pengujian dari model pengukuran disajikan pada gambar 4.2.

\section{Hasil dan Pembahasan}

\subsection{Implementasi Sistem}

Implementasi sistem terdiri dari dua halaman utama yaitu halaman administrator dan halaman pengunjung. Sistem memiliki satu input dan satu proses. Sementara output adalah Dashboard untuk mengetahui tingkat penerapan HMI, digram pie untuk karateristik jenis kelamin responden, diagram batang untuk hasil analisa kriteria usability dan diagram analisis pareto untuk membantu melihat prioritas masalah yang harus segera diselesaikan dan yang tidak harus diselesaikan.

\section{Input}

Fasilitas input sistem diakses melalui halaman administrator. Fasilitas ini dirancang dan digunakan untuk dapat memasukkan data hasil kuesioner dalam bentuk excel. Format kolom file data yang di upload dikonfigurasikan dengan field pada database yang digunakan. Gambar 6. menunjukkan halaman administrator web aplikasi.

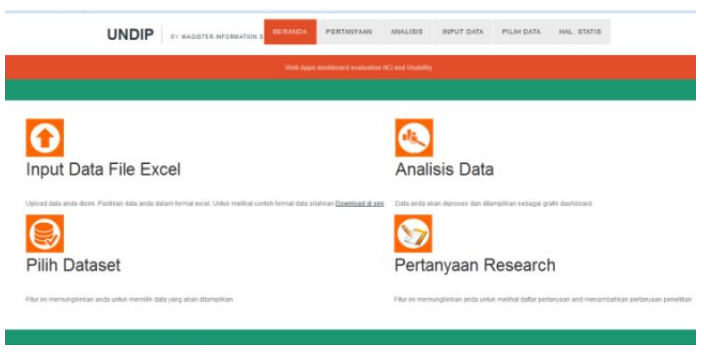

Gambar 6. Halaman administrator web aplikasi

Administrator memiliki hak akses untuk mengelola web aplikasi seperti melakukan upload data dan melakukan proses analisis, menentukan dataset dan mengelola pertanyaan penelitian. Sementara Tabel 3 merupakan contoh format data file upload. Format data yang telah dikonfigurasikan dengan field pada database MySQL dapat di download pada halaman administrator.

Tabel 3. Format data file upload

\begin{tabular}{|c|c|c|c|c|c|c|c|c|}
\hline \multirow{2}{*}{ Jns_Kel } & \multicolumn{4}{|c|}{ ERROR } & \multicolumn{4}{|c|}{ MEMORABILITY } \\
\cline { 2 - 9 } & $\mathbf{X 1}$ & $\mathbf{X 2}$ & $\mathbf{X 3}$ & $\mathbf{X 4}$ & $\mathbf{X 5}$ & $\mathbf{X 6}$ & $\mathbf{X 7}$ & $\mathbf{X 8}$ \\
\hline L & 4 & 4 & 4 & 4 & 4 & 4 & 5 & 4 \\
\hline L & 4 & 4 & 3 & 4 & 4 & 4 & 3 & 3 \\
\hline P & 4 & 5 & 4 & 4 & 5 & 4 & 4 & 4 \\
\hline P & 5 & 4 & 3 & 4 & 5 & 3 & 5 & 3 \\
\hline P & 4 & 3 & 2 & 3 & 3 & 2 & 3 & 3 \\
\hline P & 4 & 5 & 4 & 5 & 3 & 5 & 5 & 5
\end{tabular}

\section{Proses}

Proses dilakukan dengan menggunakan perhitungan nilai indeks yang melibatkan data master 
hasil upload untuk menghasilkan suatu output sebagaimana yang telah ditentukan pada kerangka sistem Gambar 5. Pada Gambar 7 menunjukkan analisis data, sementara Gambar 8 merupakan pseudocode untuk proses analisis data.

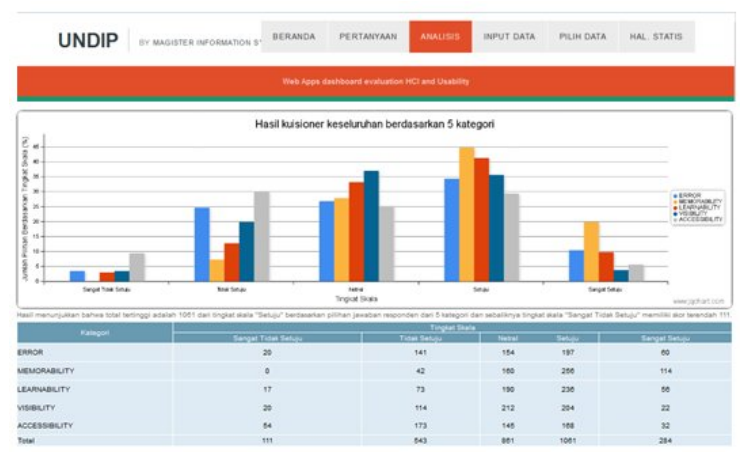

Gambar 7. Form proses analisis data

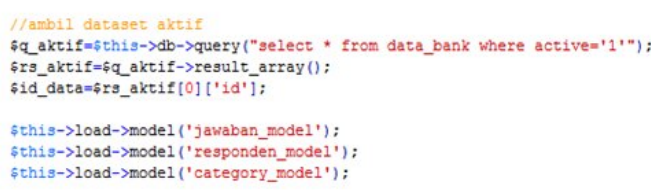

\$total_p['STS'] =round (\$total ['STS']/\$total_pertanyaan*100, 1); Stotal P['TS'] =round (Stotal ['TS']/Stotal pertanyaan*100, 1); $\$$ total_p['N'] =round (\$total ['N'] $/$ total pertanyaan*100, 1): stotal p ['s']=round (stotal ['s']/\$total pertanyaan*100, 1): \$total_p ['SS'] =round (\$tota1 ['SS']/\$total_pertanyaan*100, 1);

Gambar 8. Pseudocode proses perhitungan nilai indeks

\section{Output}

Output merupakan hasil dari proses perhitungan nilai indeks yang menyediakan informasi tentang kualitas usability, hasil analisis kriteria usability, karateristik responden, diagram pareto dan tabel point usability (Gambar 9).

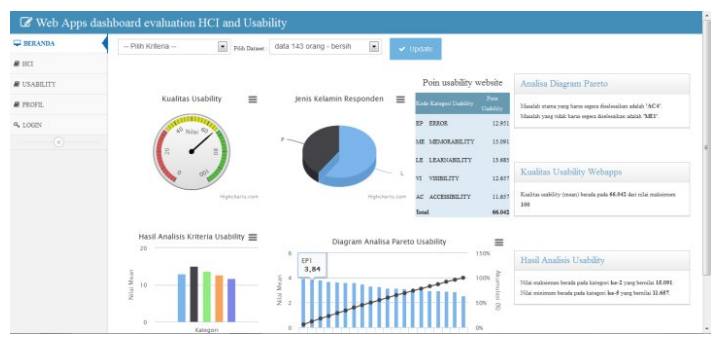

Gambar 9. Halaman utama web aplikasi dashboard

Hasil akhir penelitian ini adalah usulan perbaikan berupa prinsip dan tekinis desain interface yang mencakup integrasi dari informasi teks dan informasi visual., menu navigasi untuk operasional web, pengaturan scrolling dan paging serta penggunaan teknik CSS untuk konsistensi desain, penggunaan flash untuk grafis dan visual. Prinsip dan teknik desain dapat dilihat pada tabel 4.2. Hasil analisis kriteria usability pada output web aplikasi disajikan pada Gambar 10 dan telah diurut mulai dari yang tertinggi sampai yang terendah.

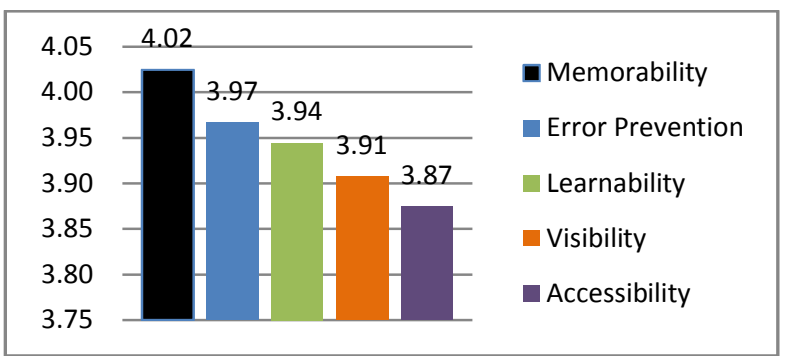

Gambar 10. Hasil analisa kriteria usability

Gambar 10 diatas menunjukkan nilai tertinggi adalah kriteria memorability $(4,02)$ nilai ini mengindikasikan bahwa cara penggunaan sistem mudah diingat dengan sekali belajar meskipun jarang digunakan, sementaranilai terendah adalah Acceessibility $(3,87)$ ini berkaitan operasional sistem seperti alat navigasi, informasi halaman atau scrolling yang kurang baik. Hasil evaluasi menunjukkan bahwa penerapan konsep HMI pada $e$ learning STIMIK AKBA Makassar telah dilakukan namum belum maksimal. Berdasarkan nilai hasil analisis deskriptif maka kriteria yang paling lemahpada sistem e-learning terletak pada krtiteria accessbility dengan nilai 3,86.

Untuk mengetahui bahwa indikator yang digunakan merupakan indikator pembentuk dari kriteria usability maka digunakan pengujian CFA. Hal ini akan membantu dalam mendukung keputusan tentang tingkat kepentingan masing-masing indikator dalam penelitian ini (Gambar 11).

Error! Reference source not found. menunjukkan hasil chi-square 375,142 dan nilai probabilitas 0,000 hal ini dapat diartikan bahwa model tidak fit. Tetapi nilai CFI 0,906 telah memenuhi standar yang direkomendasikan yaitu diatas 0,900 dan GFI dengan nilai 0,809 merupakan standar marjinal maka model dapat diterima. Selanjutnya dengan melihat hasil output standardized regression weights pada Tabel 4, terdapat indikator yang tidak valid dengan loading factor lebih kecil dari 0,6 yaitu LE2 dengan nilai 0,499 sehingga indikator ini harus dikeluarkan. Sementara nilai CR untuk full model struktural yaitu 0,933 lebih besar dari 0,7. Ini menunjukkan reliabilitas yang baik.

Hasil akhir berupa prinsip dan teknik desain antarmuka lebih fokus pada pengembangan standar untuk kualitas antarmuka sistem e-learning dan bukan pada konten pembelajaran digital yang disajikan oleh sistem e-learning (Galitz, 2007). Prinsip dan teknis desain berdasarkan pada kesalahan desain antarmuka (GUI bloopers) sistem e-learning STIMIK AKBA Makassar (Johnson, 2008). 
Tabel 4. Standardized Regression Weights

\begin{tabular}{|c|c|c|c|c|c|c|c|}
\hline & & & Estimate & S.E. & C.R. & $\mathrm{P}$ & Label \\
\hline Memorability & $<$ & Index_Usability & 448 & 038 & 11,660 & & par_16 \\
\hline Visibility & $<-$ & Index_Usability & 348 & 037 & 9,399 & $* * *$ & par_17 \\
\hline Error_prevention & $<-$ & Index_Usability & 385 & 034 & 11,466 & *** & par_18 \\
\hline Accessibility & $<-$ & Index_Usability & 434 & 037 & 11,605 & & par_19 \\
\hline Leamability & $<-$ & Index_Usability & ,500 & & & & \\
\hline EP1 & $<-$ & Error_prevention & 1,000 & & & & \\
\hline EP2 & $<$ & Error_prevention & 1,200 & 112 & 10,719 & & par_1 \\
\hline EP3 & $<-$ & Error_prevention & 1,118 &, 108 & 10,340 & *** & par_2 \\
\hline EP4 & $<-$ & Error_prevention & 1,175 & 113 & 10,421 & & par_3 \\
\hline ME1 & $<-$ & Memorability & 1,000 & & & & \\
\hline ME2 & $<-$ & Memorability & 1,012 & , 103 & 9,791 & *** & par_4 \\
\hline ME3 & $<-$ & Memorability & 1,038 & 103 & 10,066 & *** & par 5 \\
\hline ME4 & $<-$ & Memorability & 1,007 & , 103 & 9,737 & *** & par_6 \\
\hline LE1 & $<-$ & Leamability & 1,000 & & & & \\
\hline LE2 & 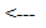 & Leamability & ,709 & ,114 & 6,217 & *** & par_7 \\
\hline LE3 & $<-$ & Leamability &, 740 & 078 & 9,480 & $* * *$ & par_8 \\
\hline LE4 & $<-$ & Leamability & 831 & 090 & 9,224 & $* * *$ & par_ 9 \\
\hline VI1 & $<-$ & Visibility & 1,000 & & & & \\
\hline VI2 & $<-$ & Visibility & 1,410 & 158 & 8,919 & *** & par_10 \\
\hline VI3 & $<-$ & Visibility & 1,084 & 148 & 7,301 & *** & par_11 \\
\hline VI4 & $<-$ & Visibility & 1,344 & 155 & 8,640 & $* * *$ & par_12 \\
\hline $\mathrm{AC} 1$ & $<$ & Accessibility & 1,000 & & & & \\
\hline $\mathrm{AC} 2$ & $<-$ & Accessibility & 924 &, 110 & 8,423 & *** & par_13 \\
\hline $\mathrm{AC} 3$ & $<-$ & Accessibility & 818 & , 101 & 8,076 & $* * *$ & par_14 \\
\hline $\mathrm{AC} 4$ & $<-$ & Accessibility & 1,027 & 103 & 10,004 & $* * *$ & par_15 \\
\hline
\end{tabular}

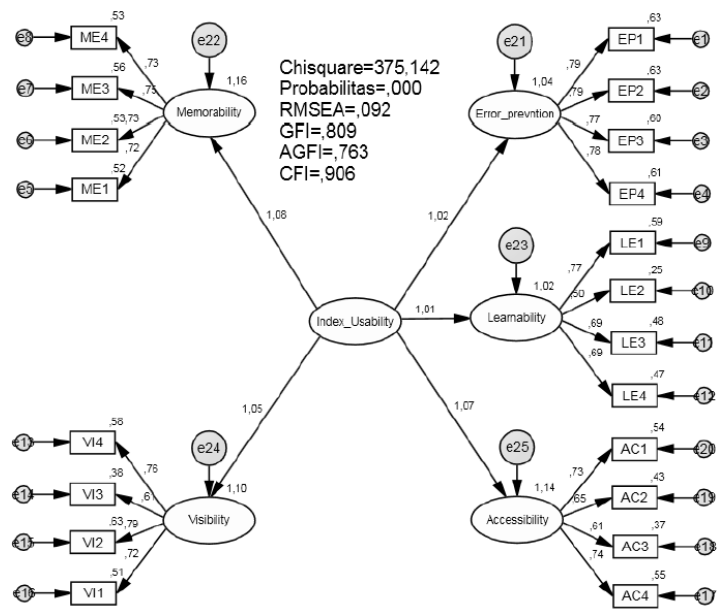

Gambar 11. Full model struktural CFA

\subsection{Evaluasi E-learning}

Evaluasi HMI dilakukan dengan melihat kesalahan desain antarmuka (GUI bloopers) pada sistem e-learning STIMIK AKBA Makassar (Johnson, 2008). Berdasarkan kesalahan desain tersebut kemudian selanjutnya dibuat perbaikan berupa prinsip dan teknis (Galitz, 2007). Masalah utama pada sistem elearning disajikan menggunakan analisa diagram pareto (Oztekin 2010). Evaluasi elearning dilakukan berdasarkan lima kriteria usability yang digunakan.

\section{Error Prevention}

Responden setuju bahwa tugas pada sistem $e$ learning mudah diselesaikan (EP1 = 4,09), termasuk pilihan atau tindakan yang salah dalam mengelola elearning dapat dibatalkan dengan mudah (EP2 = 4,04) hanya saja pesan peringatan error atau konfirmasi tidak dapat mencegah mereka untuk melakukan kesalahan $(\mathrm{EP} 3=3,83)$ tetapi ketika kesalahan itu terjadi e-learning menyediakan solusi untuk menangani kesalahan tersebut $(\mathrm{EP} 4=3,91)$. Pengujian CFA menunjukkan bahwa variabel EP4 merupakan variabel yang berkonstribusi besar membentuk variabel laten dengan nilai estimasi 9,16. Pesan peringatan error atau konfirmasi yang diberikan oleh sistem dapat dilihat pada Gambar 12 .

\section{eleaning S STHKARB}

\section{RETURNING TO THIS WEB SITE?}

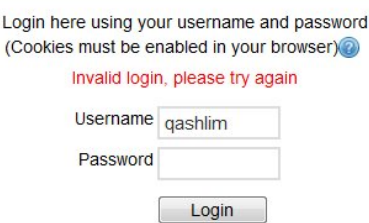

Gambar 12. Pesan error pada login

\section{Error! Reference source not} found.pesan error yang sangat penting dan memiliki arti yang sangat kuat untuk membantu pengguna agar bisa melakukan login. Pengguna yang salah memasukkan username atau password hanya diberikan pesan error yang berbunyi Invalid login, please try again, pesan ini tidak memberikan informasi yang jelas tentang letak kesalahan apakah pada username atau password?, sehingga pengguna dapat saja mencoba kembali dan menghasilkan kesalahan yang sama. Sistem ini sebaiknya menggunakan teknik validasi pemasukan data atau teknik identifikasi teks sehingga terpenuhi prinsip kejelasan (clarity).

\section{Memorability}

Secara umum kriteria ini tidak menjadi masalah pada e-learning, responden cenderung setuju bahwa informasi yang disajikan pada e-learning mudah dipahami $(\mathrm{ME} 3=4.08)$ dan mereka dapat menyelesaiakn masalah yang terjadi dengan informasi tersebut. Namun itu dianggap tidak cukup, sehingga kesediaan fasilitas FAQ (pertanyaan yang sering diajukan) pada e-learning menjadi dibutuhkan untuk memperoleh jawaban dari persoalan-persoalan yang umum terjadi $(\mathrm{ME1}=4,05)$. Pengguna telah mengetahui dengan baik cara penggunaan sistem $(\mathrm{ME} 4=4.01)$ sehingga mereka dapat menyelesaikan tugas-tugas mereka pada sistem e-learning. Hanya saja menu navigasi membutuhkan beban mengingat yang berat $(\mathrm{ME2}=3,96)$. Pengujian CFA menunjukkan bahwa ME2 merupakan variabel utama pembentuk kriteria memorability dengan nilai estimasi 0,819 . Gambar 13 merupakan halaman yang 
menyajikan informasi yang menuntuk beban mengingat pengguna.

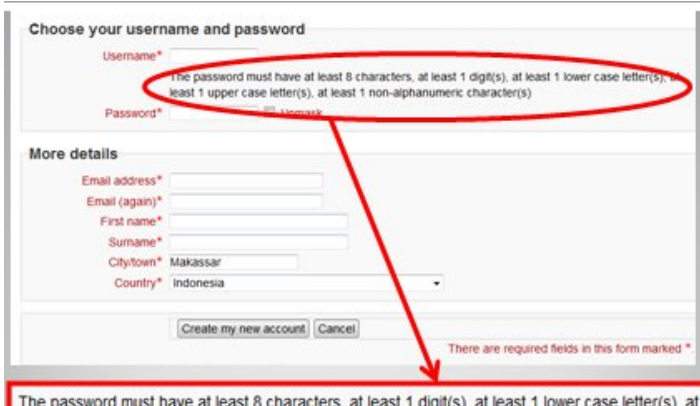

The password must have at least 8 characters, at least 1 digt(s). at least 1 lower case letter(s), at least 1 upper case letter(s), at least 1 non-alphanumenic character(s)

Gambar 13. Halaman membuat akun e-learning

Gambar 13 menunjukkan sebuah halaman untuk membuat akun e-learning yang mana pengisian pasword, pengguna diminta untuk memasukkan kombinasi angka dan huruf tertentu sebagai aturan kemanan. Hal ini jelas menjadi sebuah informasi yang memberikan beban mengingat yang berat kepada pengguna dan tidak seharusnya dilakukan terlebih lagi dengan panjangnya instruksi yang diberikan. Pengguna sebaiknya tidak diberi aturan atau batasan dalam membuat password atau kode PIN dan sebaiknya membiarkan mereka untuk menyusun password mereka sendiri karena ini memungkinkan pengguna untuk membuat password sesuai keinginan mereka dan apa yang mereka anggap mudah untuk diingat serta menghindari bentrokan yang mana banyak pengguna ingin menggunakan password yang sama untuk beberapa e-mail atau domain. Selain itu sistem harus menyediakan fasilitas untuk mengganti password dan solusi alternatif untuk dapat membuka akun dan menemukan kembali password mereka apabila mereka lupa dengan password.

Pengguna dapat mengenali sistem e-learning dari tampilan awal (LE2 = 4,02) hal ini mendukung pengguna untuk dapat mengingat cara menggunakan sistem e-learning (memorability). Sebagian besar pengguna setuju bahwa sistem e-learning mudah digunakan $(\mathrm{LE} 1=3,99)$ dan mereka dapat dengan cepat mengetahui cara penggunannya $(\mathrm{LE} 3=3,94)$ tertapi apabila terjadi kesalahan maka mereka akan kesulitan untuk menyelesaikan kesalahan tersebut (LE4 = 3,82). Ini berkaitan dengan kebutuhan fasilitas FAQ (ME1) dan penanganan kesalahan pada variabel (EP4).

Pengujian CFA yang menunjukkan bahwa indikator LE4 berkonstribusi besar membentuk variabel laten learnability dengan nilai 0,843 maka solusi persoalan ini harus segera terpenuhi pada sistem. Pengembang sistem sebaiknya mengetahui bahwa orang tidak suka menghabiskan waktu lama untuk belajar bagaimana menggunakan sistem. Orang ingin memulai langsung dan menjadi kompeten tanpa harus melakukan banyak usaha. Solusi desain antarmuka yang sederhana tetapi mampu memberikan kebutuhan pengguna secara kompleks merupakan desain yang sangat disarankan untuk memenuhi prinsip learnability

\section{Visibility}

Pada kriteria ini sistem e-learning tidak menyediakan menu navigasi yang mudah terlihat $(\mathrm{VI1}=3,88)$ dan informasi halaman untuk mengetahui dihalaman mana pengguna berada (VI4 = 3,85 ) serta link alternatif untuk mengakses mata kuliah tanpa harus kembali kehalaman awal (VI2 = $3,86)$. Hal ini membuat pengguna tidak setuju dengan indikator yang diberikan pada kriteria visibility. Hanya saja tampilan elearnig mudah diakses dan ditampilkan pada halaman web browser (VI3 = 4.09). Ini membuat pengguna tidak harus menuggu lama untuk melihat tampilan e-learning pada halaman browser. Indikator ini dapat mempengaruhi indikator yang lain, pengujian CFA juga menunjukkan bahwa indikator VI2 mempunyai konstribusi besar dalam membentuk visibility dengan nilai 0,781 (Gambar 14).

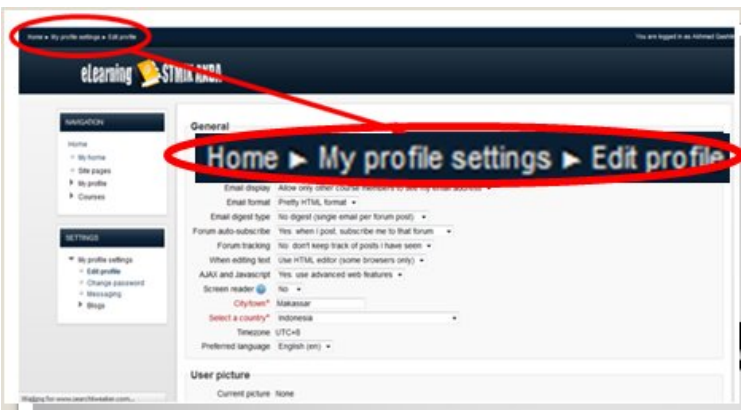

Gambar 14. Informasi halaman website

Pada Gambar 14 menunjukkan informasi berupa isyarat di halaman mana pengguna berada dan di mana halaman yang telah dikunjungi. Namun pengguna tidak dapat secara langsung melihat informasi tersebut, karena bar navigasi dibagian atas halaman tidak menyoroti halaman yang sedang terbuka. Secara tekniks prinsip navigasi telah terpenuhi pada sistem ini namun menjadi masalah pada prinsip pelacakan gerakan mata (eye tracking). Hal ini mempengaruhi efesiensi pengguna untuk menemukan informasi tersebut termasuk ukuran font, dan penggunaan simbol grafis berupa ikon.

\section{Accessibility}

Sebagian besar jawaban responden tidak setuju pada empat indikator yang terdapat pada kriteria accessibility. Saya tidak harus menggulir layar kekiri dan kekanan untuk melihat kontent $(\mathrm{AC} 4=3,75)$ ini adalah nilai terburuk untuk sebuah desain antarmuka namun tetapi hal ini diimbangi oleh fitur, kontent dan 
tulisan pada sistem e-learning yang mudah dibaca $(\mathrm{AC} 3=3,97)$ sehingga tidak memperparah accessibilitas dari sistem e-learning. Hasil pengujian CFA menunjukkan bahwa indikator AC2 tentang simbol grafis untuk menu berkonstribusi besar membentuk variabel laten accessibility dengan nilai 0,815 hal ini perlu ditingkatkan pada sistem $e$ learning. Menu navigasi e-learning ditunjukkan pada Gambar 15.

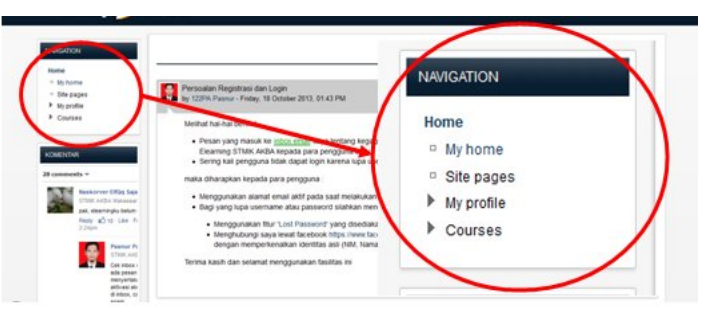

Gambar 15. Menu navigasi tanpa simbol grafis

Gambar 15 menunjukkan halaman sistem e-learning yang mana menu navigasi tidak memiliki simbol grafis. Simbol grafis pada setiap menu navigasi secara alami menyampaikan makna dari sebuah perintah. Penggunaan simbol grafis harus memperhatikan kesesuaian antara simbol yang digunakan dengan maksud dari menu atau perintah. Sementara diagram pareto menunjukkan bahwa masalah utama e-learning terdapat pada kriteria Accessibility yaitu indikator AC4 nilai persentase akumulative $100 \%$ sehingga harus segera dilakukan perbaikan.

Gambar 16 menunjukkan halaman forum yang berisi komentar pengguna, ini merupakan antarmuka yang sangat rumit, tidak efisien dan tidak efektif serta tidak terasa nyaman pada mata. Halaman hanya dapat dilihat apabila mouse diklik sambil menggeser scrolling secara horizontal (kekiri dan ke kanan) sementara itu scroll pada mouse hanya dapat digeser dengan mudah dari atas ke bawah. Walaupun sesungguhnya halaman ini dapat digerakkan dengan menggunakan keyboard, namun sebaiknya menggunakan tombol next page.

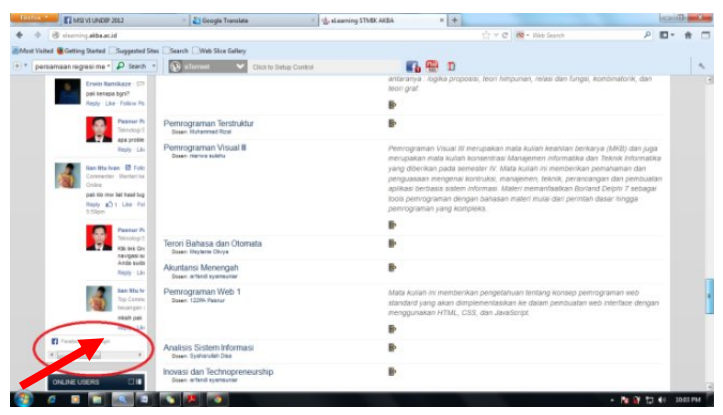

Gambar 16. Scrollbar layar secara horizontal

\subsection{Masalah Utama Elearning}

Hasil evaluasi HMI menggunakan kriteria usabilitypada sistem e-learning disajikan dengan diagram pareto berdasarkan nilai rata-rata dari seluruh indikator (Gambar 17). Hal ini akan membantu untuk mengetahui masalah utama yang harus segera diselesaikan dan yang tidak harus segera diselesaikan. Nilai rata-rata digunakan karena secara deskriptif nilai rata-rata setiap indikator dengan tegas menunjukkan suatu indikator mendapat respon positif atau negatif, sedangkan berdasarkan nilai loading factor pada pengujian CFA, diperoleh nilai estimasisetiap indikator berdasarkan tinggi atau rendahnya tingkat kepentingan yang berkonstribusi membentuk variabel laten sehingga tidak menunjukan respon positif atau negatif yang diberikan oleh responden (Tabel 5).

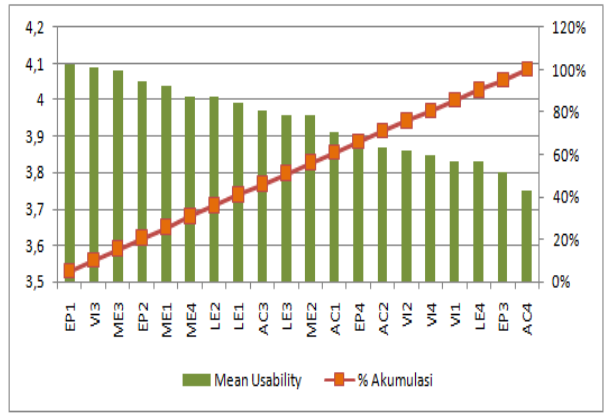

Gambar 17. Diagram analisa pareto nilai usability

Tabel 5. Nilai rata-rata seluruh indikator usability

\begin{tabular}{|c|c|c|c|c|}
\hline No & Variabel & Indeks & $\begin{array}{c}\text { Persentase } \\
\text { (\%) }\end{array}$ & $\begin{array}{c}\% \\
\text { Accumulative }\end{array}$ \\
\hline 1 & VI3 & 4,23 & 5,20 & $5 \%$ \\
\hline 2 & EP2 & 4,11 & 5,19 & $10 \%$ \\
\hline 3 & EP1 & 4,09 & 5,17 & $16 \%$ \\
\hline 4 & ME3 & 4,09 & 5,14 & $21 \%$ \\
\hline 5 & LE2 & 4,09 & 5,12 & $26 \%$ \\
\hline 6 & LE1 & 4,06 & 5,08 & $31 \%$ \\
\hline 7 & ME1 & 4,05 & 5,08 & $36 \%$ \\
\hline 8 & ME4 & 4,01 & 5,06 & $41 \%$ \\
\hline 9 & AC1 & 3,97 & 5,03 & $46 \%$ \\
\hline 10 & AC3 & 3,97 & 5,02 & $51 \%$ \\
\hline 11 & ME2 & 3,96 & 5,02 & $56 \%$ \\
\hline 12 & LE3 & 3,94 & 4,96 & $61 \%$ \\
\hline 13 & AC2 & 3,94 & 4,95 & $66 \%$ \\
\hline 14 & EP4 & 3,92 & 4,91 & $71 \%$ \\
\hline 15 & VI2 & 3,92 & 4,89 & $76 \%$ \\
\hline 16 & VI4 & 3,92 & 4,88 & $81 \%$ \\
\hline 17 & EP3 & 3,89 & 4,86 & $86 \%$ \\
\hline 18 & LE4 & 3,88 & 4,86 & $90 \%$ \\
\hline 19 & VI1 & 3,83 & 4,82 & $95 \%$ \\
\hline 20 & AC4 & 3,75 & 4,76 & $100 \%$ \\
\hline Total Nilai Indeks & 79,62 & & \\
\hline & & & & \\
\hline
\end{tabular}


Error! Reference source not found. 17 nilai diurutkan dari kiri ke kanan mulai ranking tertinggi hingga terendah. Hal ini membantu melihat permasalahan yang terpenting untuk segera diselesaikan (ranking terendah) sampai dengan yang tidak harus segera diselesaikan (ranking tertinggi). Ranking terendah merupakan kebutuhan pengguna yang dianggap prioritas. Ini merupakan partisipasi pengguna dalam menciptakan ide-ide desain. Dari hasil analisis diagram pareto dapat dilihat indikator yang paling lemah terdapat pada kriteria Accessibility yaitu indikatorAC4 (Saya tidak harus menggulir layar kekiri dan kekanang untuk melihat kontent) dengan nilai rata-rata 3,75 dan nilai persentase akumulative $100 \%$ sehingga harus segera dilakukan perbaikan.

\section{Kesimpulan dan Saran}

Hasil analisis deskriptif menunjukkan bahwa kriteria memorability dengan nilai rata-rata 4.02 adalah nilai tertinggi sementaraaccessibility dengan nilai rata-rata 3,87 merupakan kriteria yang paling rendah pada sistem e-learning. Sementara itu hasil pengujian first-order CFA diperoleh bahwa indikator pembentuk dari variabel laten error prevention, memorability, learnability, visibility dan accessibility menunjukkan nilai loading faktor yang berpengaruh secara signifikan dalam membentuk variabel-variabel laten penelitian. Ini merupakan tahap untuk menemukan masalah HMI (diagnosis)dan selanjutnya dirumuskan solusi perbaikan HMI.

Usulan perbaikan HMI berupa prinsip dan teknis lebih difokuskan pada pengembangan standar untuk kualitas antarmuka dalam sistem e-learning dan bukan pada konten pembelajaran digital yang disajikan pada sistem e-learning. Usulan perbaikan merupakan faktor desain halaman web yang mencakup integrasi yang tepat dari penyajian informasi teks dan informasi visual., grafis, struktur menu navigasi, kontrol, pengaturan scrolling dan paging sertapenggunaan CSS untuk konsistensi desain. Kriteria usability merupakan kriteria yang paling relevan untukdapat mengevaluasi antarmuka sistem. Hasil evaluasi menunjukkan penerapan aspek HMI pada e-learning telah dilakukan namum belum maksimal.

Adapun saran-saran dalam penelitian ini adalah:

1. Penelitian HMI selalu menuntut keterlibatan dari manusia, utamanya calon pengguna sistem agar dapat mengetahui karateristik dan kebutuhan pengguna. Hal ini tentunya menimbulkan banyak tantangan misalnyamenemukansubyek yang tepat, meyakinkan kepada mereka untuk benar-benar ingin terlibat dalam penelitian dan ini merupakan hal yangsulit dan banyak memakan waktu, terutama untukevaluasi padasistem yang dirancanguntukkhusus populasitertentu.
2. Prinsip dan teknis HMI mendukung keberhasilan sebuah software yang tidak hanya efektif tetapi juga lebih interaktif.

3. Evaluasi HMI perlu dilakukan dengan kriteria usability yang lain, dan metode evaluasi yang lain yang lain.

\section{Ucapan Terima Kasih}

Kami mengucapkan terima kasih kepada Ketua STMIK AKBA Makassar beserta sivitas akademik yang telah membantu dalam menyelesaikan penelitian ini.

\section{Daftar Pustaka}

Bevan, N., 2009. International standards for usability should be more widely used. Journal Of Usability Studies, Vol. 4, Issue 3, 106-113.

Bhuasiri, W., Xaymoungkhoun, O., Zo, H., Rho J., and Ciganek, A.P., 2012. Critical success factors for e-learning in developing countries: A comparative analysis between ICT experts and faculty, Computers \& Education (58) 843-855.

Chalmers, A.P., 2003, The role of cognitive theory of human-computer interface. Computers in Human Behavior (19) 593-607.

Campbell, J.L., 1996. The development of human factors design guidelines, International Journal of Industrial Ergonomics (18) 363-371.

Ferdinand, A.T. 2006. Metodologi Penelitian Manajemen, Edisi II, Badan Penerbit Universitas Dipenogoro, Semarang

George, S.R. and Otrakji, A.C., 2007. First Impressions Last A Lifetime: Effect Of Interface Type On Disorientation And Cognitive Load, Computers in Human Behavior 23 (23) 525-535.

Galitz W.O., 2007. The Essential Guide to User Interface Design: An Introduction to GUI Design Principles and Techniques, Third Edition Wiley Publishing, Inc.

Ghozali I. and Fuad, 2008. Structural Equation Modeling, Badan Penerbit undip, Semarang.

Hair J.F., Black W.C. dan Babin B.J., 2010. Multivariat Data Analysis, Seven Edtion. Pearson Prentice Hall.

Hewett, T.T., Baecker, R., Card, S., Carey, T., Gasen, J. and Mantei, M., 2009. ACM SIGCHI curricula for human-computer interaction. ACM.

Hsu, C.M., Yeh, Y.C. and Yen J., 2009. Development of design criteria and evaluation scale for web-based learning platforms. International Journal of Industrial Ergonomics (39) 90-95.

Hollender, N., Hofmann, C., Deneke, M. and Schmitz, B., 2010. integrating cognitive load theory and concepts of human-computer interaction. Computers in Human Behavior (26) $1278-1288$. 
Latan, H., 2013. Model Persamaan Struktural., Teori dan Impelementasi AMOS 21.0., Penerbit Alfa Beta Bandung.

Lazard, J., Feng H.J. and Hochheiser, H., 2010. Research Methods In Human Computer Interaction, A John Wiley and Sons, Ltd Publication.

Johnson, J., 2008. GUI bloopers 2.0 : common user interface design don'ts and dos, Morgan Kaufmann Publishers is an imprint of Elsevier, USA.

Lodico, M.G., Spaulding D.T. and Voegtle K.H., 2006. Methods In Educational Research, John Wiley \& Sons, Inc Publisher

Nielsen, J., 1993. Usability engginering, San Francisco, ISBN 0-12-518406-9.

Moha, N., Gaffar A. and Michel, G., 2007. Remote. Usability valuation of Web Interfaces, Human Computer Interaction Research In Web Design an Evaluation, Idea Group Inc. is publisher 273-229.

O'Connell, T.,A. and Murphy E.,D., 2007. The Usability Engineering Behind User-Centered Processes for Web Site Development Lifecycles, Human Computer Interaction Research In Web Design an Evaluation, Idea Group Inc. is publisher. 1-21.

Oztekin, A., Kong, Z.J., and Uysal., O., 2010. Use Learn: a novel checklist and usability evaluation method for elearning systems by criticality metric analysis. International Journal of Industrial Ergonomics (40) 455-469.
Oztekin, A., Delen D., A. Turkyilmaz and Selim Zaim, 2013. A machine Learning-based Usability Evaluation Method for ELearning Systems, Decision Support Systems (56) 63-73.

Preece, J., Rogers Y. and Sharp H., 2002. Interaction design : beyond human-computer interaction, John Wiley \& Sons, Inc Publisher

Rosenberg and Jeffrey M., 2001. E-learning: Strategies for Delivering nowledge in the Digital Age, McGraw-Hill Professional

Sawasdichai, N., 2007. A Qualitative Study in User's Information-Seeking Behaviors on Web Sites: A User-Centered Approach to Web Site Development, Idea Group Inc. is prohibited 4276.

Sener, B. and Wormald, P., 2007. evaluation of HCI concepts for defining product form, see front matter Design Studies (29) 12-29.

Sugiyono, 2003. Statistika untuk penelitian, CV Alfabeta, Bandung.

Zhang, Z., 2007. Usability Evaluation, Human Computer Interaction Research In Web Design an Evaluation, Idea Group Inc. is publisher. 209-228.

Zhang, P., and Galletta, D., 2006. Foundations of Human-Computer Interaction in Management Information Systems: An Introduction, Advancesin Management Information Systems (5) $1-18$. 